\title{
SOCIAL MEDIA IN HIGHER EDUCATION AND ITS EFFECT ON GLOBAL CHALLENGE
}

\author{
Harisa Mardiana \\ Study Program Information Technology, Faculty of Science and Technology \\ Universitas Buddhi Dharma, Tangerang, Indonesia \\ E-mail: harisa.mardiana@buddhidharma.ac.id
}

APA Citation: Mardiana, H. (2019). Social media in higher education and its effect on global challenge. Indonesian Journal of Learning and Instruction, 2(1), 35-46. doi: 10.25134/ijli.v2i01.1682.

Abstract: My interest of doing the research is to investigate the effect of social media in higher education on globalization. As the learning process changes, social media takes a step ahead to present itself to support the learning process in campus. Furthermore, students can communicate and share everything about the content of learning with their peers, lecturers, staff and others. The changes refer to available demand on access toward contents, schedules, and news, in different time, location and digital devices that provide the user with the chance to interact through comments, feedback and creative participation. The objective of the research is to describe the problems faced by the stakeholders of the higher education regarding the use of social media in higher education context. The research found that ignorance or lack of preparation were the most significant challenges. In fact, innovation in learning has converged with all application in mobile device, and the change of learning has led to the new management. The design of the research was a mixed method research quantitative and qualitative method. Data collection technique was done through observation, questionnaires and interview and data analysis. The result of the research showed that social media in higher education need to be implemented in university. And the effect in higher education needed to be incorporated into curriculum for the learning by social media and the adoption of social media as a teaching and learning process including the program of elearning.

Keywords: Benefit of social media; effect in global challenge; higher education; innovation in social media, online learning.

\section{INTRODUCTION}

With industrial revolution 4.0 going on these days, an education follows the era, it means that all the technology use for learning is changed rapidly. Technology development will change the way of life, work and learning. There are a number of lessons that will be lost but there are new lessons that will grow and eventually everyone will align their expertise to keep up with technological progress (Gray, 2016). By mastering technology, learning can be maximized in the future without suffering the consequences. For instance, the students could communicate easily using smartphones, tablets, and other gadgets. In educational context, students are able to "plug in" virtually whenever they desire to connect within their learning process either inside or outside the classroom (Russell, 2017).

Many researcher predict that industrial revolution 4.0 will necessitate profound the change in major aspects of education such as content, delivery pedagogy and structure management of education (Hasheeb, 2018). Seemingly, universities and other higher institutions are expected to be open to anyone motivated to learn, thus requiring these higher institutions to notice issues through social experience involvement in the activities. Social media has come to help connecting people and to find resources of learning, and given the impact to the higher education leading the improvement of the 


\section{Harisa Mardiana}

Social media in higher education and its effect on global challenge

students' learning process (Senouci \& Kherrous, 2015). Emphasis on certain skills and new content must be added and new programs developed to meet the demands of change.

The problem is that some of the higher educations have often ignored this advanced technology. For instance, the learning process that the students experience is still conducted in the class and the curriculum content still unformatted in digital device to give the interaction to the user such as lecturers, students, staff and members of faculty. The effect leads to a gap that is wide in which on-demand access about contents, schedules, news anytime, anywhere and the campus is very rigid to open itself in social media.

Previously, some journals written by Germain (2016) have indicated that with the industrial revolution, the role of internet especially on social media and have been a great audience connector not only with prospective students but also with prospective parents. With reaching out to engage with applicants on Facebook or Twitter which constitutes a robust social media campaign, along with such creative features as students-run blogs, can lure prospective students while a stale online presence can turn them off.

According to Griesemer (2012), changes in the pedagogy which is later on followed in the course, the faculty must set up the effective uses of several social media to approach students' learning. In this case, social media is the place to interact between campuses and students and stake holders where they can communicate and share everything about campuses. Another researcher Roger (2017) indicated that even though the characteristics of technologies integration and the blurring lines between physical, digital and biological aspect of life are foreseen as a substantial influence over the education, social and cultural environment, there is a need to ensure that all people can continue to learn, adapt and apply relevant technologies to the dynamic learning and work environment, and readjust to cultural, economic, political and social advancement.

Moreover, when social infrastructure has failed to adapt to technological advancements to continue student-centered learning, lifelong learning and learning outcomes, it is recommended to use information communication technology (ICT) in education especially in higher education so that it can rely on ease of learning, curriculum and program with demands (Xing \& Marwala, 2017). Based on the above studies, the authors conclude that knowledge, skills, communication through the internet, especially social media are needed at this time. Delays from the institution on this matter will result in being left behind in education and all lecturers, staff, technicians and laboratory staff are required to master advanced technology. The purpose of this research is to seek the significance of the internet especially on social media in higher education, besides investigating the impact of social media in global challenge with which every campus must be open toward such new technology in industrial revolution 4.0.

The value of social media is in the connection with the media to publish of matter, which is currently interchangeable terms, because people can create new media without being social, but one cannot create social media without being in new media (Southren, 2013). Social media is leading to real-time transparency which makes the production control, and management processes more flexible and can transform to be challenging for higher educations that have started their journey to transformation since they provide interactive website, improve the learning service and others (Bauer, Hämmerle, Schlund, \& Vocke, 2015). The advance of new information technologies and a new ways of communicating science through social media create an easily available and accessible to everyone to learn. The new reality as demonstrated in communicating emerging issue with online media (Szabo, 2014). The pervasive changes to communication 
between organizations, communities and individuals, social media aspects improve the frequency of usability, immediacy and permanence and spend more time of the site. And a new media refers to on-demand access to content anytime, anywhere and on any digital device and it is interactive to the user gives comments, feedback, creative participation (Divol, Edelman, \& Sarrazin, 2012).

As Selwyn (2012) argued that social media tend to focus either on the very prosaic of growing numbers of educationalists are beginning to consider the possible significance that it likely gives the implications of social media for education practice and provision-especially in terms of higher education which engages with an audience in a new media channels, social media is seen as viable tool for university communicators due to its low cost, immediacy, and used by a large number of students (Kelleher \& Sweetser, 2012).

Ken \& Taylor (2012) indicated that the understanding of framework has five principles of features that it is successfully integrating public relations dialogues onto the web: mutually, is the recognition or organization-public

propinquity, is the temporality and spontaneity of interactions with publics; empathy, is the supportiveness and confirmation of public goals and interests; risk, is the willingness to interact with individuals and publics on their own terms; and commitment, it is the extent to which an organization gives itself over to dialogue, interpretation and understanding in its interaction with publics. Based on the scholar opinions and research studies above, it clearly establishes that the increase of technological tools such as social media by millennial, higher education institutions must create dialogue on traditional Internet sites sparks inquiry into how well the institutions are able to utilize social media to interact with the current and future publics to challenge globalization. Following the same reasoning, the adoption of social media in globalization can be defined as the use of social media to support a higher education business which the innovation adoption process in an institution can be divided in two phases: initiation and implementation (Damanpur, 1991).

The future universities and other institutions are not taught only for the young, they are expected to become more open to people of all ages who wish to further their education to inevitable in global world. The formation of strategy of education-social media-globalization as Mytton (2011) defined what programs to run, on what platforms and for which audience groups. The key concern of using social media is the security, insufficient time for managing activities and lack of internet connection. The university management must control the internet, and each of the class should use social media in a certain time. The faculty and lecturers give the time limit to use social media in campus in order to give other class use social media and internet (Osborne, 2011).

Another key performance indicators to measure the performance of particular channels and outputs about social media data can potentially provide rapidly feedback from the audiences and the changes in audience relations described in the introduction that possible to draw on audience data to influence the content of individual program of the web content on the basis web metrics information. (Gillespie, Mackay, \& Webb, 2011); (Mackay \& Tong, 2011). The term of social media has been used to describe emerging new technologies that are important public relations such as describing the interactive nature of blogging; within social media or new media can be broadly applied to all interactive technologies. Social media in education integrates the learning and teaching environments and it may have new form of inquiry, communication, collaboration, identity work or have positive cognitive, social and emotional impact (DiVall \& Kirwin, 2012); (Greenhow \& Robelia, 2009b). For instance, on social network sites (e.g. Facebook), the interaction, 


\section{Harisa Mardiana}

Social media in higher education and its effect on global challenge

collaboration, information and resource sharing is encouraging participation and critical thinking; thus increased peer support and communication about course content and assessment when inter-cultural language learning and positive effects on the expression of identities and digital literacies, particularly for marginalize the group of learning (Manca \& Ranieri, 2013).

According to Palmer and Koenig (2009), the college and universities use social media to recruit and research prospective students. Online behavior can have an important consequence for young people to utilize of making decision. In addition, the new students will have social media to help them to get information about higher education institution to connect with others with similar interests before the new students apply to the universities. The advantages of social media in many universities have successfully use as a promotional tools. Many institutions of higher education use social media as a part of their target to develop interact with the target audience (Dabbagh \& Kitsantas, 2012).

As a compliment to the course, social media works best to connect with the students outside of the class, but the lecturers need to pre-developed the course to help students stay engage the lesson and build the avenue to contact between lecturer and students or students and students in managing the communication platform. The use of social media in education provide students ability to get more useful information, to connect with learning groups and other educations systems that make education convenient ( Anderson \& Dron, 2017). Hence, social media has gained credibility as a trusted source of information and platform where higher education can interact with the prospect students, lecturers, staff or technician. The benefit of online learning and resources is shared through social media especially social network in which the valuable knowledge is gained through social media such as analytics and insights on various topics or issues for study purposes. (Ganis \& Kohirkar, 2016).
The effect of education strategy is measured in deep consideration of human condition in which the new technology and shifting economic power impact to the people in that institution ( Penprase, 2018). As the world is increasingly interconnected, the deep intercultural understanding and abiding respect of freedom and human right approach the favor of global curriculum and a residential context that is found in the institution. And this approach will maximize the development of intercultural and interpersonal skills which is a hallmark of future learning in the 21 st century

\section{METHOD}

The purpose of the research is to conduct the mixed method research in which to seek the significance of social media in higher education and also to investigate the impact of social media in global challenge with university or institution must be open to a new technology in industrial revolution 4.0.

The subject sampling selection was applied to 26 respondents. The questionnaires were used as instrument to elicit the return responses of respondents regarding to social media use from each division such as 5 staff, 8 lecturers, 3 employees (technician laboratories), and 10 students. The questionnaires were taken in week 2 month of June, 2018. The result of questionnaires will be analyzed using excel MS. Moreover, series of works had been undertaken to collect data for the research. Related literature was reviewed and questionnaire was developed by the author. The research was also followed by semistructured interviews conducted with the researches ( Jamshed, 2014).

Creation and deployment of the research are mainly to get significance of social media in higher education. There are 14 questions developed and had crosschecked to measure respondents' use of social media in campus or institution. Prior to the research, an extensive exploratory phase was conducted to issue the importance to the user or nonusers of social media in higher education. The questionnaires are divided 
into 5 categories: (1) the role of social media in supporting the communication between each other; (2) the frequency of social media use; (3) the role of social media in learning process; (4) the benefit of using social media; (5) the availability of social media services or support in campus.

A detailed description of this research uses a quantitative and the instrument use is questionnaires which are used to elicit the return responses from the respondents. The questionnaires contain some questions which are related to the followings: 1) The role of social media in supporting the communication between each other; 2) The frequency of social media use; 3) The role of social media in learning process; 4) The benefit of using social media; and 5) The availability of social media services or support in campus.

Data collection was constituted faculty of Science and Technology, Universitas Buddhi Dharma, Tangerang, Indonesia. The questionnaires were used as an instrument to elicit the return responses of respondents regarding to social media use from each division such as from 5 staff, 8 lecturers, 3 employees (technician laboratories), and 10 students. The questionnaires were taken in week 2 month of June, 2018. The result of questionnaires will be analyzed using excel MS.

\section{RESULTS AND DISCUSSION}

The result of the research study is to determine how significant the effect of social media toward higher education is, as well as analyzing the significance on the on global challenge. From the finding the research study examined the data above that most of members of university (staffs, employees, lecturers and students) have positive impact on social media usage in higher education. To find the result of data, the research excel MS and the result of the study is shown in table 1 .

Table 1. The use of social media of members in Higher Education $(N=18)$

The Use of Social Media Members in Higher Education

The role of social media in supporting the communication between each other

$\begin{array}{ccccccc}\text { No } & \text { Variables } & \text { Yes } & \text { No } & \begin{array}{c}\text { Don't } \\ \text { know }\end{array} & \text { Means } & \text { St.dev } \\ 1 & \text { Communication outside } & 12 & 6 & 0 & 2.65 & .493 \\ 2 & \text { Favorite in campus } & 15 & 3 & 0 & 2.82 & .393 \\ 3 & \text { Method of Communication } & 12 & 3 & 3 & 2.47 & .800 \\ & \text { Total } & 39 & 12 & 2 & 7.94 & 1.686\end{array}$

The frequency of social media use

$\begin{array}{lcccccc}4 & \text { Using social media/networking } & 18 & 0 & 0 & 3.00 & .000 \\ 5 & \text { Popularity of social media } & 12 & 3 & 3 & 2.59 & .712 \\ 6 & \text { Preferable of work online } & 11 & 3 & 4 & 2.35 & .862 \\ \quad \text { Total } & 41 & 6 & 7 & 7.94 & 1.574\end{array}$

The role of social media in learning process

$\begin{array}{lcllllc}7 & \text { Online learning process } & 13 & 5 & 1 & 2.65 & .606 \\ 8 & \text { Using top social media for teaching } & 15 & 0 & 3 & 2.65 & .786 \\ 9 & \text { Valuable for teaching and learning } & 10 & 3 & 5 & 2.24 & .903 \\ & & 38 & 8 & 9 & 7.54 & 2.295\end{array}$

Total

The benefit of using social media

\begin{tabular}{lcccccc}
10 & Valuable online space & 12 & 2 & 2 & 2.65 & .702 \\
11 & Valuable in teaching online & 10 & 4 & 2 & 2.29 & .849 \\
12 & Valuable in teaching by social & 12 & 4 & 0 & 2.76 & .437 \\
\hline media & & &
\end{tabular}


Harisa Mardiana

Social media in higher education and its effect on global challenge

\begin{tabular}{|c|c|c|c|c|c|c|}
\hline & Total & 34 & 10 & 4 & 7.70 & 1.988 \\
\hline \multicolumn{7}{|c|}{ The availability of social media services or support in campus } \\
\hline 13 & Provided by University & 18 & 0 & 0 & 3.00 & .000 \\
\hline \multirow[t]{2}{*}{14} & Requirement by University & 18 & 0 & 0 & 3.00 & .000 \\
\hline & Total & 36 & 0 & 0 & 6.00 & .000 \\
\hline
\end{tabular}

From data above, the research found that the first highest is the frequency of using social media in higher education was deemed as the most important factor indicated with the highest score (41). From 18 members of respondents, indicated that all of the 18 members of university use social media/ network and 12 members think that social media is also popular. The 3 members said that they never think that social media or social network is popular, and 11 members said that they prefer to work by online, for example to send and receive data by email, because it is very fast. As Harvey, B., (2012) indicated that in term of substantive creation of content it appears that the philosophy of social media lies at the heart of people's ethos to encourage choosing the comments that they will post in which all the members of university will find the knowledge or expertise in the process of communication. And Selwyn (2012) commented that the effect of social media will give to the individuals learn differently and start the new technology to embrace the challenge of vision to create and share their own knowledge in their contents and activities which will take longer when they want to continue outside of class.

The second highest is the role of social media in supporting the communication between each other. The score is 39 . From 18 members of university found that 12 members use social media to communicate all the times and only 6 members do not use social media, because they think that social media destroys the lives. Social media is the favorite way to communicate inside and outside of campus. Beside cheaper than texting, they can send and receive messages, images and videos. The method of communication is such as chatting, commenting, sharing, sending or receiving images, video and etc. Gartner predicted that social media will transform communication and data-sharing in the enterprise. It was predicted that by 2019 , internal social media will achieve as much importance within the organization as email and the telephone have contributed (Gartner, 2013).

The third highest is the role of social media in learning process. The score is 38 , from 18 members, 13 members use online learning process is the best way for teaching and learning, 5 members do not use online learning process, they prefer to have conventional learning process and 1 member do not know about online learning process. There are 10 members who think that social media is valuable for teaching and learning, and 3 members do not think that social media is valuable for teaching and learning and 5 members do not know about the valuable of social media for teaching and learning. And means for role of social media in learning process is 2.65 and std. dev is 0.606 . As a new media refers to on-demand access to content anytime, anywhere and on any digital device and it is interactive to the user gives comments, feedback, creative participation (Divol, Edelman, \& Sarrazin, 2012). Moreover, the implication for using social media in higher education will ask the students to understand the interactions of communication where the questions of rules and etiquette are clearly crucial (Divol, Edelman, \& Sarrazin, 2012).

The fourth highest is the benefit of using social media for communication and learning process. There are 12 members who considered that social media is valuable online space, 2 members do not think that valuable online space and 2 members think that they don't know about the valuable online space. The means is 2.65 and std. dev is 0.702 . Another point is the valuable in teaching online. There are 10 members think that teaching online is valuable, 4 members do not think that teaching online is valuable and 2 members do not know about the 
valuable in teaching online. Means is 2.29 and std. dev is 0.849 . The last for benefit of using social media is the valuable in teaching by social media. It is mentioned that 12 members think that teaching by social media is valuable and 4 members do not think that teaching by social media is valuable and none of the member do not know about valuable in teaching by social media. Means is 2.76 and std. dev. is 0.437 . The innovation of the core of construct in social media is the readiness, the establishing of attitude toward technology has given differences to determine the characteristic of students who refers to the spread of ideas, gives the technical information and move from sources to the students' contents (Rogers, 2003). It triggers the interest to educators who perceive these technologies as beneficial in higher education (Kumar \& Vigil, 2011).

The last or the fifth highest is the availability of social media services or support in campus which has 2 dimensions; there are provided by university, requirement by university. All of members think that university is provided of social media and also it is requirement by university. None of members think that university do not provide and do not require of social media. University supports the online teaching and communication. Means for this is 3.00 and std.dev. is 0.00 . The university and faculty force the students to think only of themselves and their own personal development which is able to work closely in teams, because the working team requires students to develop skills in group dynamics, compromise, debate, persuasion and organization, leadership and management skills (Cogburn, 2011). The university and faculty is forced to build the curriculum for the learning by social media and the interactive learning will be accelerated of the stratification of education with the availability of funding to create and adopt social media as a teaching and learning process (Anderson, Boyles, \& Rainie, 2012).

Advanced technologies are very important in industrial technology 4.0 and it brings the possibilities to a new solutions to global challenges, employment opportunities for jobs need to be invented (Brown-Martin, 2017). As a result, the vital education is to develop human potential rather human machines. The education systems designed for an industrial is now automated require transformation from a system based on the facts and procedures to one that actively applies that knowledge to collaborative problem solving (Schwab, 2016). Most campus' members are responsible for the creation and sharing of their profile or their personal ephemeral. Social media supports the communication between all members is mainly to communicate with each members in institution. The interview to 4 members, from 26 members, 15 members or half of the members mentioned that social media is one of the most favorite ways to communicate and it is cheaper to communicate by social media such as WhatsApp or Facebook.

The frequency of the use of social media indicated that most of the members use social media networking, from 26 members, there are 18 members use social media all the time. As a matter of fact, most of the university members have social media and have group to make easier to communicate. But, some of the members argued that they have the popular social media as a part to communicate. Although most members use many social media, such as Facebook, Twitter, Instragram, WhatsApp and Line but only 3 members think that social media is not important to communicate. It is because; the 3 members have a technologically problem on internet. However, the associations between social media usage behavior, personal background and work value are having positive benefits with the staff. It indicates that staff workers with different demographic characteristics have different social media usage behavior pattern ( Ying-chao LIn, Nhat- Hanh Le, \& Khalil, 2012); ( Tolliday, 2017); ( Baruah, 2012).

Nevertheless, the innovation of the core of construct in social media is the readiness, the establishing of attitude toward technology has given differences to determine the 


\section{Harisa Mardiana}

Social media in higher education and its effect on global challenge

characteristic of students who refers to the spread of ideas, gives the technical information and move from sources to the students' contents (Rogers, 2003). The challenge for higher education to adopt social media as their teaching and learning process in globalize era is by using technology and new technologies which product the new knowledge and dissemination of data, information and knowledge. Some technologies include the internet, World Wide Web, CD-ROM and printed, audio, video and other electronic media form which allow the students and academics to move from being sages on the stage into the role of the guide on the side and assist students in gaining the skills and abilities required to acquire and utilize knowledge contained in various form around the world (Dabholkar \& Bagozzi, 2002). Since the research only concern with the response of the respondents towards the significance of social media in educational field further research might be specifically focused on the background of respondents.

Using social media in the higher education is increasing interaction between students, lecturers and members of institutions. This benefit may help the members who have lack of knowledge and skills in technological use, the job descriptions or in studying ( Datko, 2015). One of the members stated that the students and lecturers mentioned that social media is the place to find the source of learning. There are many sources of learning related to the subjects, and effective ways to increase students' engagement. The features of social media resources have attracted the attention of millions of people around the globe, which is capable of drawing the attention of students to the learning opportunities provided by the academic institution (Faizi i, Afia , \& Chiheb, 2013). Lecturers and students can collaborated with fellow from the social media and the students and lecturers may feel comfortable to express themselves and to share the resources or ideas on social media (McLoughlin \& Lee, 2007).
There is no surprise that university and institutions have embraced social media. The growth of communicating and sharing experience on social media sites helps grow the popularity of university or institutions ( Ridley, 2017). Using the power of social media with different networks and engaging the content, the university or institution stay connect with each other and the university or institute has already installed the requirement of internet to make easier for the university or institution to connect each other (UBD, 2018). Finally, todays', it's time for universities or institutes to keep in touch with the world. Globalization calls on all of us to keep in touch with each other to make it easier to get information and colleagues.

\section{CONCLUSION}

As the learning process changes, it is a challenge for social media as a tool to take a part in the changes. The effect of social media in higher education will give the impact of social life and real life for the universities, faculties and business industries need to be more active with connecting with students through social media (Ganis \& Kohirkar, 2016). Also, they will give to the individuals learn differently and start the new technology to embrace the challenge of vision to create and share their own knowledge in their contents and activities to outside of the class. The security is component of structure in new media of improvement, mission, vision to education, and carry out the research through approach characterize by ethnics, autonomy, responsibility and anticipation. The changes in knowledge creation which interdisciplinary approach should be taken and non-scientific forms of knowledge should be explored (Hall, 2014).

The responsibility for the creation and sharing their profile or their personal ephemeral is the substantive creation content that appears in social media which lies at the heart of people's ethos to encourage choosing the comment that they will post in which they find the knowledge or expertise the process of teaching and learning. As the 
Indonesian Journal of Learning and Instruction Volume 2, Issue 1, April 2019

$21^{\text {st }}$ century learning process changes, social media will take a step ahead to present itself in turn on the learning media and they can communicate, share everything about the content learning which it can be seen as pervasive change as a new media on digital device and give the interaction to the users by having the comments, feedback (Deborah, McIlrath, \& Huitt, 1995). With the specific challenge of higher education to face a new management and the power of individual and states, the teaching and learning process will come to global challenge for the $21^{\text {st }}$ century learning process.

To address information technology (IT) problems, the efficient and systematic of infrastructure especially in internet connection is a set of stage that the university or institutions to have. The university or institution must employ the technicians in order to help the lack of resembling plugand-chug. The digital strategy from the academic domain can further strengthen a university's commitment to internet technology by helping to create the articulate environment where the faculty, staff, and administrations feel more comfortable embarking on new line initiatives in and out of the classroom (UBD, 2018); (Waite \& Wheeler, 2016).

\section{ACKNOWLEDGMENT}

I wish to thanks various people for their contribution to this research. Dr. rar. nat. Gregoria Ilya as Dean of Faculty of Science and Technology for the valuable support on this research, my husband, sons for lovely supports.

\section{REFERENCES}

Anderson, T., \& Dron, J. (2017). Integrating learning management and social networking systems. IItalian Journal of Educational Technology, 25(3), 5-19. doi: 10.17471/2499-4324/950.

Anderson, J. Q., Boyles, J. L., \& Rainie, L. (2012). The future impact of the Internet on higher education: Experts expect more-efficient collaborative environments and new grading schemes; they worry about massive online courses, the shift away from on-campus life. Retrieved from Pew Research Center http://www.pewinternet.org/files/old-
p-ISSN 2614-8250, e-ISSN 2614-5677

https://journal.uniku.ac.id/index.php/IJLI

media/Files/Reports/2012/PIP_Future_of_High er_Ed.pdf.

Baruah, T. D. (2012). Effectiveness of social media as a tool of communication and its potential for technology enabled connections: A micro-level study. International Journal of Scientific and Research Publications, 2(5), 1-10.

Bauer, W., Hämmerle, M., Schlund, S., \& Vocke, C. (2015). Transforming to a hyper-connected society and economy - towards an industry 4.0. Procedia Manufacturing, 3, 417-424. doi: 10.1016/j.promfg.2015.07.200.

Brown-Martin, G. (2017). Education and the fourth industrial revolution. Retrieved from Learning $\{$ Re\}imagined: https://medium.com/learningre-imagined/education-and-the-fourthindustrial-revolution-cd6bcd7256a3.

Cogburn, D. L. (2011). Globalization, knowledge, education and training in the information age. South Africa: SCRIB.

Dabbagh, N., \& Kitsantas, A. (2012). Personal learning environments, social media, and selfregulated learning: A natural formula for connecting formal and informal learning. Internet and Higher Education, 15(1), 3-8.

Dabholkar, P. A., \& Bagozzi, R. P. (2002). An attitudinal model of technology based selfservice: Moderating effects of consumer traits and situational factors. Journal of Academy of Marketing Science, 30(3), 184-201.

Damanpur, F. (1991). Organizational Innovation: A meta-analysis of effects of determinants and moderators. Academy of Mangement Journal, 34(3), 555-590.

Datko, J. (2015). Social networking sites in higher education: Potential benefits and drawbacks. 10th international conference DisCo: From analog education to digital education (pp. 1-9). Prague: ePortfolio in the Czech Republic after the DisCo 2015 conference, 10.

Deborah, A., McIlrath, \& Huitt, W. G. (1995). The teaching-learning process: a discussion of models. Retrieved from Educational Psychology Interactive: http://www.edpsycinteractive.org/papers/model tch.html.

DiVall, M. V., \& Kirwin, J. L. (2012). Using Facebook to facilitate course-related discussion between students and faculty members. Americal Journal of Pharmaceutical Education, 76(2), 1-5.

Divol, R., Edelman, D., \& Sarrazin, H. (2012). Demystifying social media. Retrieved from McKinsey

http://www.mckinsey.com/business-

functions/marketing-and-sales/ourinsights/demystifying-social-media.

Faizi i, R., Afia , A. E., \& Chiheb, R. (2013). Exploring the potential benefits of using social media in education. iJEP, 3(4), 50-53. 


\section{Harisa Mardiana}

Social media in higher education and its effect on global challenge

Retrieved from http://dx.doi.org/10.3991/ijep.v3i4.2836.

Ganis, M., \& Kohirkar, A. (2016). Social media analytics. New York: IBM Press.

Gartner. (2013). Gartner says 80 percent of social business efforts will not achieve intended benefits through 2015. Retrieved from Gartner Newsroom:

https://www.gartner.com/newsroom/id/231921 5.

Gillespie, M., Mackay, H., \& Webb, A. (2011). Designs \& devices: Towards a genealogy of audience research methods at the BBC World Service 1932-2010. Participations: International Journal of Audience Research $8(1)$.

Gray, A. (2016, January 19). The 10 skills you need to thrive in the fourth industrial revolution. Retrieved from World Economic Forum: https:/www.weforum.org/agenda/2016/01/the10-skills-you-need-to-thrive-in-the-fourthindustrial-revolution/.

Greenhow, C., \& Robelia, E. (2009b). Informal learning and identity formation in online social network. Learning, Media and Technology, 34 (2), 119-140.

Hall, S. J. (2014). How higher education institutions utilize social. Digital Commons@Georgia Southern University Honors Program Theses, $1-50$.

Hasheeb, A. A. (2018, January 10). Higher education in the era of IR 4.0. Retrieved from New Straits Times:

https://www.nst.com.my/education/2018/01/32 3591/higher-education-era-ir-40.

Jamshed, S. (2014). Qualitative research methodinterviewing and observation. Journal of Basic and Clinical Pharmacy, 5(4), 87-88. doi: 10.4103/0976-0105.141942.

Kelleher, T., \& Sweetser, K. (2012). Social media adoption among university communicator. Journal of Public Relation Research, 24(2), 105-122.

Kumar, S., \& Vigil, K. (2011). The net generation as preservice teachers: Transferring familiarity with new technologies to educational environments. Journal of Digital Learning in TEachers Education, 27 (4), 144-153.

Mackay, H., \& Tong, J. (2011). ll Chinah: Digitad service researinteractivity, the global conversation and wor. Journal of audience \& Reception Studies, 8(1).

Manca, S., \& Ranieri, M. (2013). Is it a tool suitable for learning? A critical review of the literature on facebook as a technology-enhance learning environment. Journal of Computer-assisted Learning, 29(6), 487-504. doi: 10.1080/17439880902923606.

McLoughlin, C., \& Lee, M. J. (2007). Social software and participatory learning: extending pedagogical choices with technology affordances in the web 2.0 era. In R. Atkinson \& C. McBeath (Eds), Proceeding of the 24th ASCILITE Conference, Singapore, December 2-5 (pp. 664-675). Singapore: ICT.

Osborne, N. (2011). Opportunity, risk, and policy. Retrieved from IBM, Developer Work: https://www.ibm.com/developerworks/library/ wa-ind-educ-social-media1/.

Penprase, B. E. (2018). The fourth industrial revolution and higher education. In N. W. Gleason (Eds.), Higher education in the era of the fourth industrial revolution (pp.207-229). Yale-NUS College, Singapore: Palgrave McMillan. doi: 10.1007/978-981-13-0194-0 9.

Ridley, D. (2017). How today's colleges and universities are using social media. Retrieved from Vital Design https://vtldesign.com/digitalmarketing/social-media/how-todays-collegesand-universities-are-using-social-media/

Rogers, E. M. (2003). Diffusion of Innovations. New York: Collier Macmillan Publisher.

Russell, J. (2017). Social Media in Higher Education: Strategies, Benefits, and Challenges. Retrieved from Hootsuite: https://blog.hootsuite.com/social-media-inhigher-education/.

Schwab, K. (2016). The fourth industrial revolution. Geneva: World Economic Forum ${ }^{\circledR}$ ISBN-13: 978-1-944835-01-9.

Senouci, A., \& Kherrous, A. (2015). The impact of globalization on education. Submitted to the Department of English as Partial Fulfillment for the "Master Degree" in Literature and Civilization., 1-50.

Southren, J. (2013). The difference between new media and social media. Retrieved from Jane Southern- Engage, Inspire, Empower: http://southren.ca/the-difference-between-newmedia-and-social-media/.

Szabo, L.-V. (2014). The Future of Communication: From new media to postmedia. Procedia Social and Behavioral Sciences, 163, 36-43.

Tolliday, R. (2017). Sensis social media report 2017 Chapter 1 - Australian and social media. Melbourne, Australia: Sensis.

UBD, P. (2018). Tentang UBD. Retrieved from Website UBD: https://buddhidharma.ac.id/keunggulan-ubd/.

Waite, B. C., \& Wheeler, D. A. (2016). Understanding using social media on college campuses - practical guide for higher educational professionals. London: Rowman \& Littlefield .

Xing, B., \& Marwala, T. (2017). The 4.0 industrial revolution affecting higher education. International Journal of Management Technology, 4(2), 1-12.

Ying-chao Lin, J., Nhat- Hanh Le, A., \& Khalil, S. (2012). Social media usage and work values 
Indonesian Journal of Learning and Instruction Volume 2, Issue 1, April 2019

the example of facebook in Taiwan. Social
p-ISSN 2614-8250, e-ISSN 2614-5677 https://journal.uniku.ac.id/index.php/IJLI

Behavior and Personality, 40(2), 195-200. 


\section{Harisa Mardiana}

Social media in higher education and its effect on global challenge 